\title{
In Memoriam: Ivan Daskalov: 1933 - 2004
} Alvin Wald*

\author{
Address: Columbia University, Department of Biomedical Engineering, 351 Engineering Terrace: MC 8904, 1210 Amsterdam Ave., New York, NY \\ 10027, USA \\ Email: Alvin Wald* - aw7@columbia.edu \\ * Corresponding author
}

Published: 07 July 2004

Received: 29 June 2004

BioMedical Engineering OnLine 2004, 3:22 doi:10.1 186/1475-925X-3-22

Accepted: 07 July 2004

This article is available from: http://www.biomedical-engineering-online.com/content/3/I/22

(C) 2004 Wald; licensee BioMed Central Ltd. This is an Open Access article: verbatim copying and redistribution of this article are permitted in all media for any purpose, provided this notice is preserved along with the article's original URL.

\begin{abstract}
Ivan Daskalov [1933-2004] was a friend who will be missed by many. Neither the quality of a man nor the concept of a friendship can be defined with words. We may only say that both will be missed.
\end{abstract}

Friendship is a unique human relationship. It is a mutual freely consensual activity between two people. Each friendship is different and inexplicable, and based on its own particulars. When you lose a friend, you lose something special, you lose a part of yourself. But that friendship is not really lost if you pass it on to others.

Ivan Daskalov was my friend. He had been ill for a while, so his death was not completely unexpected. Yet I cannot but feel that he should have been here longer. People involved in health care often somehow feel that their work in trying to conquer nature's ineluctable passage gives them and their loved ones immunity from the inevitable fate of us all. After all, that is one reason that many of us became biomedical engineers to begin with.

I met Ivan some 15 years ago at an IEEE/EMBS conference. (In truth, I am not sure just how long ago it was.) He made some very gentle comment about my presentation, and we talked for a while. That was the only time that I actually met him in person, and my first impression, which was only reinforced as I came to know him better, was that he was a true gentleman. Over the years we communicated by mail and then mostly by e-mail. Our correspondence covered many topics, but mostly was about the joys and tribulations of life. Our views meshed almost perfectly, despite our growing up in different parts of the world. Maybe it was because we were close contemporaries in time, and as children saw the world through a great war.

We exchanged small gifts: I would send him technical journals and he would reciprocate with cultural artifacts from Bulgaria. On occasion, I also sent him some literary magazines He always wanted to improve his English, which I always told him was quite good and in fact much better than my Bulgarian. His basic kindness was again shown as he sent me Bulgarian postage stamps after finding out about a young friend of mine who collects stamps. Ivan was particularly proud of his country. He recognized that Bulgaria might be a small country in terms of the world, but it had an enormous heritage of literary, architectural, and religious activities. He was particularly proud that the people of Bulgaria, alone among countries associated with the Axis Powers of World War II, protected its Jewish citizens from the barbarities of the Nazis.

When BioMedical Engineering OnLine was started, I knew that I would need help with both the actual work as well as a type of emotional support. Ivan was there for me on both counts. He took on the position of Deputy Editor and offered the first article that was published. His many research results have appeared in a wide selection of the biomedical engineering literature. 
I need not go into the many accomplishments of Ivan's career as a biomedical engineer. Suffice to say they were numerous and significant, with many collaborators in Bulgaria and throughout Europe. Through his many years, just like all of us, he had his share of disappointments, as well as a full measure of successes. His sense of humor helped him through the former, and his humility through the latter. He particularly delighted in his activities as a teacher and mentor to young researchers, having experienced such dedicated and concerned professors in his own younger days. He was appointed the first director of the Centre for Biomedical Engineering of the Bulgarian Academy of Sciences in 1994. His works have been recognized and highly appreciated throughout the biomedical engineering community, and in 2003 he was elected a Fellow of the International Academy for Medical and Biological Engineering.

Our loss is small in comparison to that of Ivan's wife, son, daughter and grandson. We offer them our most profound sympathy. We will all remember him with respect and affection.

\section{Al Wald}

\section{New York}

June 2004

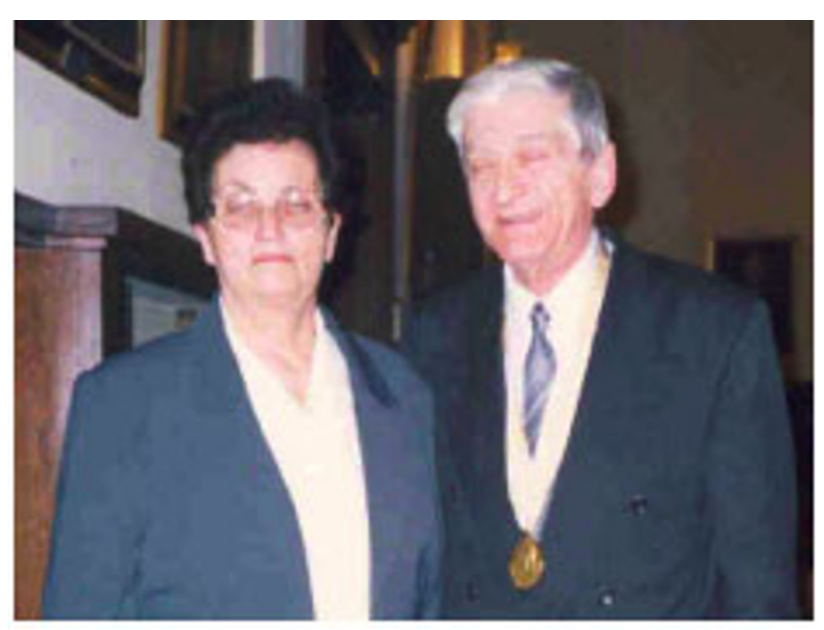

\section{Figure I}

Professor Ivan Daskalov and his wife at the Academic Lecture on the occasion of his 70th Anniversary, where he received the Order of Marin Drinov.

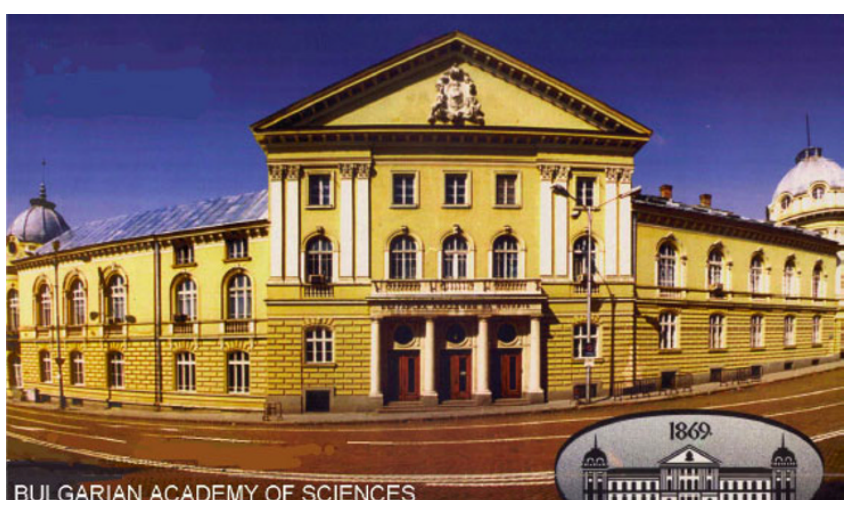

Figure 2

Presented on February 27, 2004 in The Ceremonial Hall of the Bulgarian Academy of Sciences.

Publish with Biomed Central and every scientist can read your work free of charge

"BioMed Central will be the most significant development for disseminating the results of biomedical research in our lifetime. " Sir Paul Nurse, Cancer Research UK

Your research papers will be:

- available free of charge to the entire biomedical community

- peer reviewed and published immediately upon acceptance

- cited in PubMed and archived on PubMed Central

- yours - you keep the copyright

Submit your manuscript here:

http://www.biomedcentral.com/info/publishing_adv.asp

BiolMedcentral 